\title{
A new species of skink from the Guadeloupe Archipelago (Squamata, Mabuyidae, Mabuya)
}

\author{
S. Blair Hedges ${ }^{1, *}$, Olivier Lorvelec ${ }^{2,3}$, Nicolas Barrée ${ }^{3}$, Joël Berchel ${ }^{4}$, Marion Diard Combot ${ }^{4}$, \\ Nicolas Vidal ${ }^{5}$, and Claudie Pavis ${ }^{3}$ \\ ${ }^{1}$ Center for Biodiversity, Temple University (502 SERC), 1925 N. 12th Street, Philadelphia, PA 19122, USA. \\ 2INRA, UMR0985 Écologie et Santé des Écosystèmes, Campus de Beaulieu, 35042 Rennes Cedex, Bretagne, France. \\ ${ }^{3} \mathrm{AEVA}$, Association pour l'Étude et la protection des Vertébrés et végétaux des petites Antilles, 97170 Petit Bourg, Guadeloupe, France. \\ ${ }^{4}$ Association Titè, Réserve Naturelle Nationale des îles de la Petite Terre, 97127 La Désirade, Guadeloupe, France. \\ 5ISYEB, UMR7205 MNHN-CNRS-UPMC-EPHE, Muséum National d'Histoire Naturelle, Département Systématique et Evolution, CP30 25 rue \\ Cuvier 75005 Paris, France. \\ *Corresponding author (sbh@temple.edu)
}

Article registration: http://zoobank.org/urn:Isid:zoobank.org:pub:23EF46DB-3895-4047-A71B-71273CE7F92D.

Edited by: Robert W. Henderson. Date of publication: 18 February 2016.

Citation: Hedges SB, Lorvelec O, Barré N, Berchel J, Combot MD, Vidal N, Pavis C. 2016. A new species of skink from the Guadeloupe Archipelago (Squamata, Mabuyidae, Mabuya). Caribbean Herpetology 53:1-14.

\begin{abstract}
A new species of lizard of the genus Mabuya is described from a small island in the Guadeloupe Archipelago: Terre de Bas, Îles de la Petite Terre. Mabuya parviterrae sp. nov. is allied with the other four species of Mabuya from Guadeloupe. However, it differs in scalation, coloration, and (where available) DNA sequence. Of the nine named species in the genus, only M. dominicana (from Dominica), M. desiradae (from La Désirade), and M. parviterrae sp. nov. have escaped decimation and possible extinction by the Small Indian Mongoose, Urva auropunctata. The latter two species of skinks are critically endangered, being threatened by the Black Rat (Rattus rattus) and degraded habitat that has not recovered from early land use. The Petite Terre Skink probably has one of the smallest distributions of a vertebrate species. The species consists of approximately $\mathbf{5 0}$ individuals living primarily in a dry stone wall of less than $\mathbf{5 0 0}$ square meters in extent.
\end{abstract}

Keywords: Caribbean, island, lizard, phylogeny, Reptilia, Scincomorpha, systematics.

\section{Introduction}

The distribution of one Caribbean genus of skinks, Mabuya, is centered in the Lesser Antilles where seven species (out of a total of eight) occur on Montserrat, Guadeloupe, Dominica, and Martinique. The eighth species is distributed on Hispaniola. Here we describe a ninth species of Mabuya from an islet of Guadeloupe: Terre de Bas, îles de la Petite Terre (Fig. 1).

There are five known skinks in the Guadeloupe Archipelago. Two species are known from the main islands, Mabuya guadeloupae Hedges \& Conn (Basse-Terre) and M. grandisterrae Hedges \& Conn (Grande-Terre), and three others are known from outlying islands: M. cochonae Hedges \& Conn (Îlet à Cochons), M. desiradae Hedges \& Conn (La Désirade), and Capitellum mariagalantae Hedges \& Conn (Marie-Galante). No living individual of any of these species has been seen in recent decades with the exception of $M$. desiradae (Breuil 2002; Paré \& Lorvelec 2012; Hedges \& Conn 2012; Gomès \& Ibéné 2013; Métaireau 2014) and taxonomically indeterminate populations on Terre de Bas, Îles de la Petite Terre (Lorvelec et al. 2000; Breuil 2002; Lorvelec et al. 2007; Lorvelec 2011; Hedges \& Conn 2012; Lorvelec et al. 2012; Schedwill 2014) and in Les Saintes (Angin \& Gomès 2015). The mongoose has not been introduced to îles de la Petite Terre and Les Saintes, which explains why skinks still occur there. The mon- 
goose situation on La Désirade is more complex (see below).

All of the endemic Caribbean island skinks are threatened with extinction, and 16 species already may be extinct, almost entirely from predation by the Small Indian Mongoose, Urva auropunctata (Hodgson), introduced to Caribbean islands in the late 19th century. Previously, there had been uncertainty as to whether the mongoose was the ultimate cause of the extinctions or if it was a change in land use practices (Corke 1992). Later, Hedges and Conn (2012) demonstrated a strong temporal correlation between the introduction of the mongoose and the disappearance of skinks on a diversity of islands with different habitats and human population numbers, implicating the mongoose. Studies of stomach contents of mongooses have confirmed that they are feeding on threatened ground-dwelling reptiles, including skinks (e.g., Lewis et al. 2011). Together this leaves little doubt that the introduction of the mongoose led to the extinction and decline of many species on Caribbean islands, including skinks.

Until this study, no preserved museum specimens or genetic material of skinks from Terre de Bas, îles de la Petite Terre, have been available for taxonomic study. Based on photographs, Hedges \& Conn (2012) suggested that they might be Mabuya desiradae, but noted that "further study may show that they represent a separate species." Since then, we have obtained a single preserved specimen for study, which turned out to be a female with four well-developed fetuses, thus providing a sample of five individuals for taxonomic analysis, including DNA sequence comparisons. Additional DNA samples were obtained from scale clips of live specimens. With this new information, we show below that skinks from Terre de Bas, îles de la Petite Terre, represent a new species.

\section{Materials and Methods}

The molecular and morphological methods followed Hedges \& Conn (2012). Acronyms are KU (University of Kansas, Natural History Museum), MNHN (Muséum National d'Histoire Naturelle, Paris), and SBH (Laboratory of S. Blair Hedges); some Genbank accession numbers, coincidentally, begin with "KU" but are so indicated. Abbreviations are as follows: $\mathrm{EL}$, ear length; $\mathrm{HL}$, head length; HW, head width; SVL, snout-vent length; and SW, snout width (Hedges \& Conn 2012). Genetic samples were obtained primarily from scale clips of live specimens (SBH 274694-695, 274770-772) that were released. One individual (holotype) of the Petite Terre Skink was preserved in ethanol, and later found to contain four well-developed fetuses that yielded morphological and genetic data. Two adult specimens of Mabuya desiradae from La Désirade, killed by domestic cats in the main village of Beauséjour (Fig. 1A), were salvaged by Joël Berchel for DNA and morphological data: MNHN-RA-2015.0064 (SBH 274931; genetic sample 1) collected on 5 July 2013 (16.306, -61.077) and MNHN-RA-2015.0065 (SBH 274777; genetic sample 2) salvaged on 15 July 2014 (16.304,-61.072). These two new specimens were used in addition to the only other known specimens of M. desiradae (KU 242045-046), as well as material from other species in the genus (Hedges \& Conn 2012), for comparison with the new species of Mabuya from Terre de Bas, Îles de la Petite Terre.

Sexual size dimorphism is modest in Neotropical skinks, with females being approximately $8 \%$ larger than males in four species with the largest sample sizes (Hedges \& Conn 2012). Males tend to have larger heads although the difference is slight, and sex is difficult to determine in these lizards without dissection. No statistically significant sexual dimorphism was observed in scale counts or scale shape ratios, which comprise most diagnostic characters (Hedges \& Conn 2012). Allometric change during ontogeny can affect shapes of characters, and therefore data from the fetuses were omitted for those shape characters.

DNA sequences of cytochrome b were collected from two skinks from La Désirade (GenBank accession numbers KU587588-589), 10 from Terre de Bas, îles de la Petite Terre (GenBank KU587590-599), and one from a closely related outgroup species, Marisora brachypoda (GenBank KU587600), and aligned with a sequence used in Hedges \& Conn (2012) for Mabuya dominicana (GenBank JN227561). Alignments (MUSCLE, considering amino acid translations) and best-fit model selection were performed in MEGA 6.06 (Tamura et al. 2013). A maximum likelihood (ML) analysis was performed in MEGA 6.06, unpartitioned, using the best-fitting evolutionary model, GTR + $\mathrm{G}$ (general time reversible + gamma distribution of changes). Gaps were treated as missing data. All parameters for 


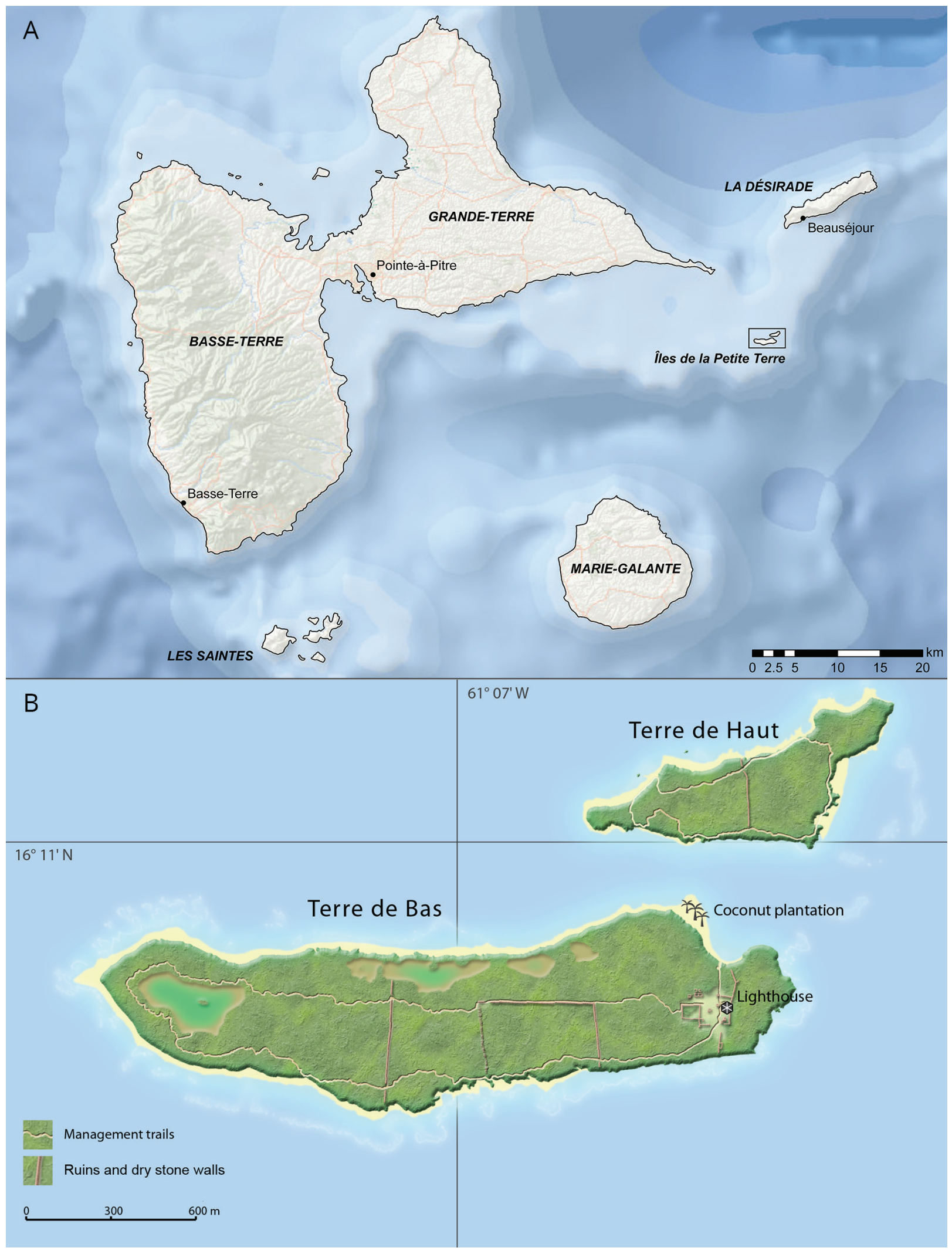

Figure 1. Map showing (A) the Guadeloupe Archipelago and (B) the îles de la Petite Terre. Rectangle in panel A indicates region shown in panel B. Shading indicates relief on land and under water (paler shading denotes shallower water). 
the $\mathrm{ML}$ analyses were estimated by the program during the run. A Bayesian phylogenetic analysis using MrBayes 3.2.5 (Ronquist et al. 2012) also was performed, again using the GTR $+G$ model. The Bayesian analysis was set to two parallel runs for five million generations, sampled every 500 generations, and each run employed three heated and one cold chain, with a temperature parameter of 0.25 . The first $25 \%$ of samples were discarded as burnin. Convergence was assessed by the standard deviation of split frequencies ( $<0.01$ in all cases). Branch support in the trees was provided by bootstrap analysis (2,000 replicates) for the ML analysis and posterior probabilities for the Bayesian analysis. Sequence divergence between the two species from the Guadeloupe Archipelago was measured for comparison with other Caribbean species reported in Hedges \& Conn (2012).

The map of the Guadeloupe Archipelago was created with ESRI software using data from DeLorme, General Bathymetric Chart of the Oceans (GEBCO), National Oceanic and Atmospheric Administration National Geophysical Data Center (NOAA NGDC), and Advanced Spaceborne Thermal Emission and Reflection Radiometer (ASTER). The map of îles de la Petite Terre was drawn with Adobe Photoshop software from an aerial photograph (BD Ortho 2004, French Institut National de I'Information Géographique et Forestière - IGN). Trails, dry stones walls, and ruins were based on a 1:5000 scale map created in 1995 by Neumuller \& Barneron, on tracing paper, in the Office National des Forêts (ONF) of Guadeloupe.

\section{Results}

The molecular phylogeny showed that Mabuya parviterrae sp. nov. and M. desiradae were each monophyletic and each other's closest relatives, compared with the more distantly-related M. dominicana (Fig. 2). Cytochrome b sequence divergence between $M$. parviterrae sp. nov. and $M$. desiradae was $0.9 \%$, approximately the same as the divergence of four closely-related species of skinks in the Puerto Rico region (Spondylurus culebrae, S. macleani, S. monitae, and S. sloanii) and corresponding to a time of separation of approximately 500,000 years ago (Hedges \& Conn 2012).

Mabuya parviterrae sp. nov.

Petite Terre Skink (Scinque de la Petite Terre, French)

(Figs. 3A-F, 4A-C, 5, 6B-D)

Mabuya mabouya mabouya_Lorvelec et al. 2000: 37 (part, Îles de la Petite Terre).

Mabuya mabouya-Breuil 2002: 267 (part, Îles de la Petite Terre).

Mabuya mabouya — Lorvelec et al. 2007: 141 (part, îles de la Petite Terre).

Mabuya mabouya-Lorvelec 2011: 1 (part, Îles de la Petite Terre).

Mabuya desiradae—Hedges \& Conn 2012: 97 (part, Îles de la Petite Terre).

Mabuya cf. desiradae —Lorvelec et al. 2012: 11 (part, îles de la Petite Terre)

Mabuya desiradae-Hedges 2014: 327 (part, Îles de la Petite Terre).

Mabuya desiradae-Angin \& Gomès 2015: 1 (part, Îles de la Petite Terre).

Holotype. MNHN-RA-2015.0059, an adult female, collected by Nicolas Barré on a dry stone wall near the middle of Terre de Bas, Îles de la Petite Terre, Guadeloupe (16.1714, -61.1207, 5 m), on 22 April 2015. Additional specimen tag SBH 274765.

Paratypes ( $\mathbf{n}=\mathbf{4}$ ). MNHN-RA-2015.0060-0063, fully-developed fetuses taken from the holotype (Fig. 3E-F). Additional specimen tags SBH 274766-769 (respectively).

Diagnosis. Mabuya parviterrae sp. nov. is characterized by (1) maximum SVL in males, $101 \mathrm{~mm}$ (released adult, possibly a male); (2) maximum SVL in females, $103 \mathrm{~mm}$; (3) snout width, 3.28-3.36\% SVL; (4) head length, 16.3-17.0\% SVL; (5) head width, 11.8\% SVL; (6) ear length, 1.11-1.59\% SVL; (7) toe-IV length, 9.44-9.69\% SVL; (8) 


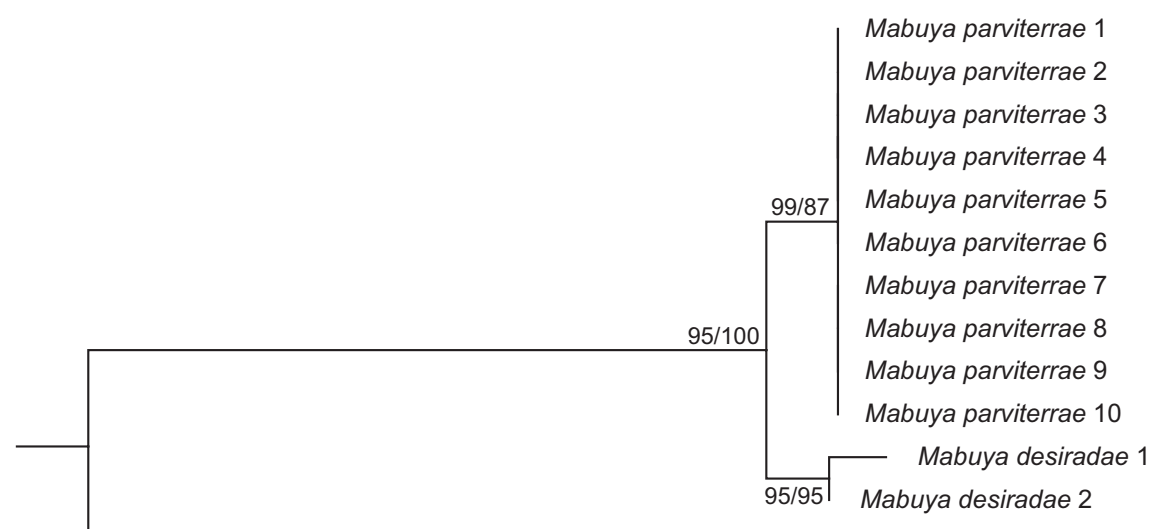

Mabuya dominicana

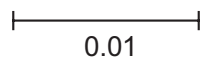

Figure 2. Phylogenetic tree of 15 individuals of three species of skinks (Mabuya) from a maximum-likelihood analysis of DNA sequences of cytochrome b. A scale bar (1\% sequence divergence) is indicated below. The numbers at nodes are support values from maximum likelihood (left) and Bayesian (right) analyses. The tree is rooted (not shown) with a species, Marisora brachypoda, in a closely related genus.

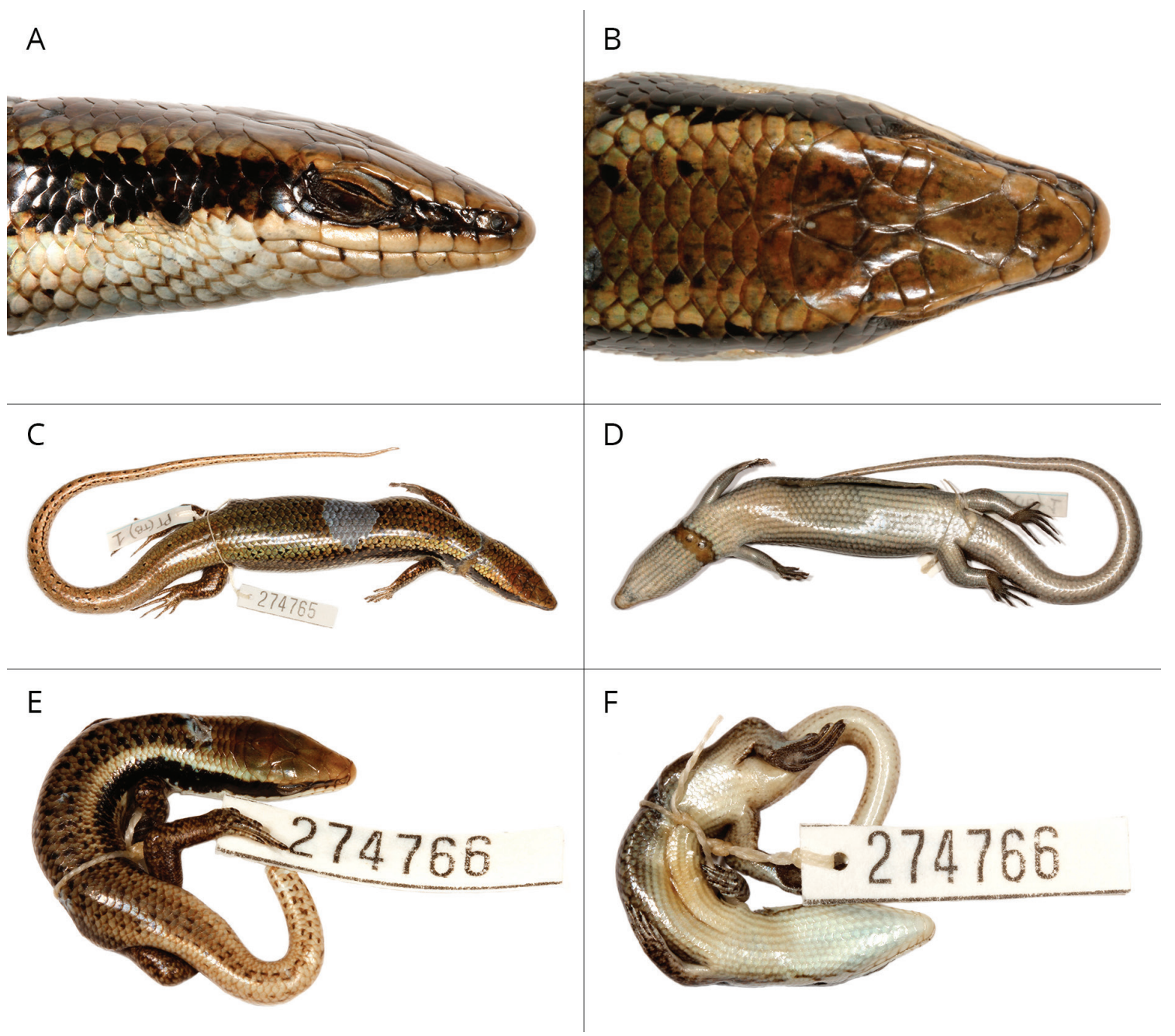

Figure 3. Mabuya parviterrae sp. nov. (A-D) MNHN-RA-2015.0059, holotype. (E-F) MNHN-RA-2015.0060, fetus of holotype. 
prefrontals, two; (9) supraoculars, three; (10) supraciliaries, four; (11) frontoparietals, two; (12) supralabial below the eye, five $(80 \%)$ or six (20\%); (13) nuchal rows, one; (14) dorsals, 56-60; (15) ventrals, 65-68; (16) dorsals + ventrals, 123-126; (17) midbody scale rows, 32-34; (18) finger-IV lamellae, 13-14; (19) toe-IV lamellae, 16-17; (20) finger-IV + toe-IV lamellae, 29-31; (21) supranasal contact, $Y$; (22) prefrontal contact, N; (23) supraocular-1/frontal contact, $\mathrm{Y}$; (24) parietal contact, $\mathrm{Y}(60 \%)$ or N (40\%); (25) pale middorsal stripe, N; (26) dark dorsolateral stripe, $\mathrm{N}$; (27) dark lateral stripe, $Y$; (28) pale lateral stripe, N; and (29) palms and soles, dark. Sample size six (includes released adult) for all characters except those size-related (characters 3-7), where only the adult holotype and released adult (possibly a male) were scored.

Within the genus Mabuya, the species from Guadeloupe and its islets are placed in the M. guadeloupae Species Group: M. cochonae, M. desiradae, M. grandisterrae, and M. guadeloupae. Mabuya parviterrae sp. nov. can be added to this group. All five species have a similarly-proportioned frontonasal scale that distinguishes them from other species in the genus (Hedges \& Conn 2012: fig. 34). They have a relatively longer frontonasal compared with M. montserratae (frontonasal length/head length $17.6-20.4 \%$ versus $16.5-16.8 \%$ ) and a shorter frontonasal compared with other species in the genus (20.5-23.9\% in M. dominicana, M. hispaniolae, and M. mabouya). In addition, M. parviterrae sp. nov. differs from M. dominicana in having a shorter, wider supranasal scale (supranasal length/ supranasal width 2.92-3.13 versus 4.57-6.57 in M. dominicana; Hedges \& Conn 2012: fig. 35), in lacking a well-defined pale lateral stripe (present in 84\% of M. dominicana), and it is probably a larger species: 103 and $101 \mathrm{~mm} \mathrm{SVL}$ in the only adults of $M$. parviterrae versus a maximum of $101 \mathrm{~mm} \mathrm{SVL}$ in 55 adults of $M$. dominicana (Hedges \& Conn 2012) where (in M. dominicana) males average $81.4 \mathrm{~mm} \mathrm{SVL}(\mathrm{n}=25)$ and females average $88.8 \mathrm{~mm} \mathrm{SVL}(\mathrm{n}=20)$ (Hedges \& Conn 2012). It is further separated from M. hispaniolae by having a shorter head (HL/SVL 16.3-17.0\% versus $17.7-19.2 \%$ in M. hispaniolae), a shorter 4th toe (T4L/SVL 9.44-9.69\% versus $10.7-11.1 \%$ in M. hispaniolae), in having supranasal contact (lacking in M. hispaniolae) and in lacking well-defined lateral and pale dorsolateral stripes (such stripes are present and well-defined in M. hispaniolae). It is distinguished from M. mabouya by having a shorter frontonasal (noted above) and a shorter 4th toe (T4L/SVL $9.44-9.69 \%$ versus $10.2-12.5 \%$ in M. mabouya). It differs from $M$. montserratae by having a relatively longer frontonasal (noted above), a shorter head (HL/SVL $16.3-17.0 \%$ versus $17.1-18.6 \%$ in M. montserratae), and a narrower head (HW/SVL $11.8 \%$ versus $12.3-13.2 \%$ in M. montserratae).

From the other species of the Mabuya guadeloupae Species Group, M. parviterrae sp. nov. differs from M. cochonae $(n=2)$ in having a shorter head (HL/SVL $16.3-17.0 \%$ versus $18.7-19.1 \%$ in M. cochonae), a shorter 4th toe (T4L/SVL 9.44-9.69\% versus 11.1-11.6\% in M. cochonae), fewer ventrals (65-68 versus 70 ), and fewer dorsals + ventrals (123-126 versus 128-132). Mabuya parviterrae sp. nov. differs from M. grandisterrae $(n=5)$ in having a shorter head (HL/SVL 16.3-17.0\% versus 17.2-19.8\% in M. grandisterrae), a higher supraciliary-2/supraciliary-3 length ratio (2.13-2.29 versus 1.67-1.79 in M. grandisterrae), and a shorter 4th toe (T4L/SVL $9.44-9.69 \%$ versus $10.2-12.8 \%$ in M. grandisterrae). Mabuya parviterrae sp. nov. differs from M. guadeloupae $(\mathrm{n}=3)$ in having fewer dorsals + ventrals (123-126 versus 128-133), fewer 4th toe lamellae (16-17 versus 18-21 in M. guadeloupae), supranasal contact versus no contact in M. guadeloupae, and a different color pattern (tan ground color with weakly developed pale dorsolateral and dark lateral stripes versus medium brown ground color with bold pale dorsolateral and dark lateral stripes in M. guadeloupae).

Mabuya parviterrae sp. nov. differs from $M$. desiradae $(n=4)$, the species with which it was initially confused, in having a shorter head (HL/SVL 16.3-17.0\% versus 18.0-19.0\% in M. desiradae), a shorter 4th toe (T4L/ SVL $9.44-9.69 \%$ versus $10.2-11.0 \%$ in M. desiradae), fewer dorsals (56-60 versus 61-63), fewer dorsals + ventrals (123-126 versus 130-134), dark palms and soles versus pale palms and soles in $M$. desiradae (both species have dark pigment below digits), little or no distinction of dark lateral band in posterior half of body versus distinct band in posterior half of body in M. desiradae; evident in preserved specimens and photos of other individuals (Paré and Lorvelec 2012; Gomès and Ibéné 2013; Métaireau 2014). The coloration difference in palms and soles of the two species (Fig. 4) was in all individuals, including those preserved in ethanol and for similar lengths of time. 
Description (Fig. 3A-D). The holotype is an adult female in good state of preservation, although with scales around body in neck region missing from injury, and a lateral body slit. SVL $103 \mathrm{~mm}$; tail complete, $168 \mathrm{~mm}$; HL $17.4 \mathrm{~mm}$; HW $13.6 \mathrm{~mm}$; SW $3.52 \mathrm{~mm}$; EL $1.66 \mathrm{~mm}$; and toe-IV length $9.74 \mathrm{~mm}$; ear opening small in size and round; toe length in the following order: $\mathrm{I}<\mathrm{II}<\mathrm{V}<\mathrm{III}<\mathrm{IV}$. In SVL, the paratypes measured $36.5 \mathrm{~mm}$ (MNHN-RA-2015.0060), $36.1 \mathrm{~mm}$ (MNHN-RA-2015.0061), $35.7 \mathrm{~mm}$ (MNHN-RA-2015.0062), and $36.6 \mathrm{~mm}$ (MNHN-RA-2015.0063). In coloration and scalation, they resembled the holotype, except as noted below. Another adult, released (101 mm SVL, $118 \mathrm{~mm}$ tail length, possibly a male based on slightly enlarged head) was captured, photographed, sampled for DNA by scale clip, and released. That individual, and others observed but not collected, resembled the type series in coloration.

Head scalation. Rostral wider than high, contacting first supralabials, nasals and supranasals. Paired supranasals in median contact, barely contacting or not contacting anteriormost loreal (barely contacting in holotype). Frontonasal heptagonal, wider than long, laterally in contact with anterior (or fused) loreal scale. A pair of quadrilateral prefrontals, separated medially, and in contact with frontonasal, both anterior and posterior loreals, first supraoculars, first supraciliaries, and frontal. Frontal pentagonal and diamond-shaped, in contact with the first supraoculars. Frontoparietals in contact with parietals and interparietal. Interparietal tetragonal and lanceolate, narrowly in contact with nuchals or not at all (narrowly in contact in holotype); parietal eye distinct. Parietals in contact with upper secondary and tertiary temporal scales. Three supraoculars, the first one being the longest and largest. Four supraciliaries, the second the longest. Nostril in central part of the nasal. A small postnasal, bordered by supranasal, loreal(s), and first supralabial. Anterior and posterior loreals fused on one or both sides of head in four of five individuals (fused on right side in holotype, no fusions in MNHN-RA-2015.0060). Two upper preoculars

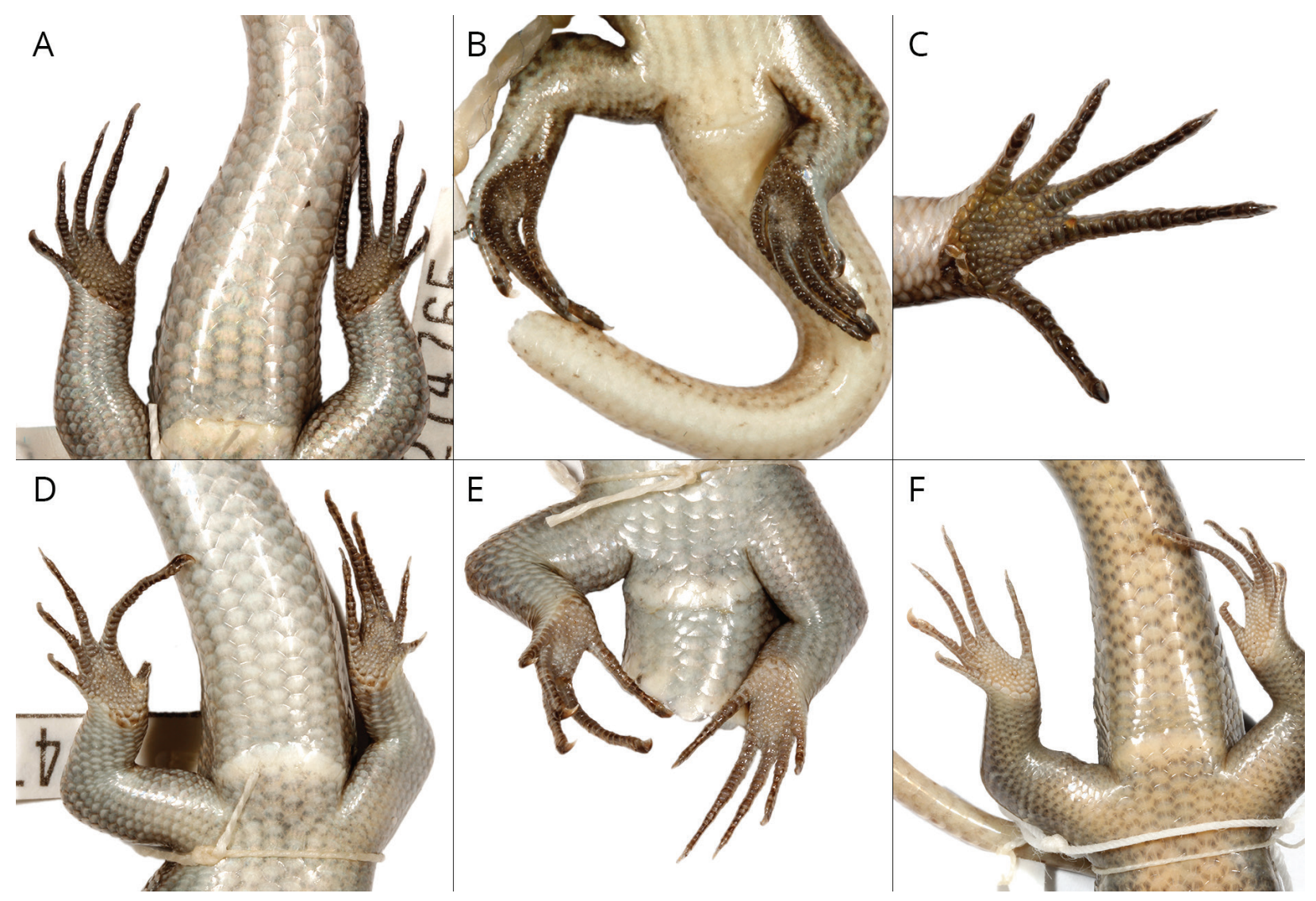

Figure 4. Comparison of sole color in M. parviterrae sp. nov. (A, MNHN-RA-2015.0059, holotype; B, MNHN-RA-2015.0060; and C, released adult) and M. desiradae (D, MNHN-RA-2015.0065; E, MNHN-RA-2015.0064; and F, KU 242045). 
and two lower preoculars. Seven supralabials, the fifth or sixth (fifth in holotype) being the widest and forming the lower border of the eyelid. Five moderately enlarged scales behind eye comprising the postoculars; similar to temporal scales but smaller. One primary temporal, two secondary temporals, and 2-3 tertiary temporals; all imbricate, smooth, cycloid, not distinctly delimited from the scales on the nape and the sides of the neck. Seven infralabials. Mental scale wider than long. Postmental scale and three pairs of adjoining chin shields in contact with anterior infralabials. First two pairs of chin shields in contact medially; third and fourth pairs separated by smaller cycloid scales.

Body and limb scalation. One row of paired nuchal scales. Other scales on nape similar to dorsals. On lateral sides of neck, scales slightly smaller. Dorsal scales cycloid, imbricate, smooth, 56-60 (58 in holotype) in a longitudinal row; ventrals similar to dorsals; 65-68 (65 in holotype) in a longitudinal row; 32-34 (34 in holotype) scales around midbody. No distinct boundaries between dorsals, laterals, and ventrals. Scales on tail and limbs similar to dorsals, except smaller on limbs. Palmar and plantar regions with small tubercles, subequal in size and delimited by a surrounding region of flatter scales. Subdigital lamellae smooth, single, 13-14 (14 in holotype) under finger-IV and 16-17 (17 in holotype) under toe-IV. Four preanals similar in size to adjacent ventral scales. Median subcaudal scales gradually increasing in relative size from base to tip of tail.

Pattern and coloration. In preservative, dorsal ground color dark greenish-brown with small dark brown spots, distributed on body, tail, and limbs. Limb coloration slightly darker than dorsum and similar to lateral stripes. Dark dorsolateral stripes absent. Dark lateral stripes present, dark brown, extending from loreal region to hindlimbs, although breaking into a series of dark spots around midbody and virtually unnoticeable in posterior half of body. Pale middorsal stripe absent. Pale dorsolateral stripes weakly present, medium gray, extending from behind eye to midbody. Pale lateral stripes absent. Ventral surface of body without pattern. Underside of hands and feet, including surfaces below digits, distinctly dark gray. In life (holotype and released adult), coloration was similar except that there was no greenish tinge present (Fig. 5) and throat, abdomen, and base of tail were pale beige. Some individuals observed on the rock wall, but not collected, had orange-tinged scales on side of head.

Distribution. The Îles de la Petite Terre (Fig. 1B) is a micro-archipelago composed of two islets: Terre de Bas $\left(1.17 \mathrm{~km}^{2} ; 1.11 \mathrm{~km}^{2}\right.$ without its four lagoons) and Terre de Haut $\left(0.32 \mathrm{~km}^{2}\right)$. The species is known only from Terre de Bas. Despite searches, it has not yet been found on nearby Terre de Haut.

Ecology and conservation. The initial skink observed on Terre de Bas, 19 April 1998 (Lorvelec et al. 2000) was found in a forest on sand near a lagoon. Four additional individuals were observed in May 2010, along an old dry stone wall that runs north-to-south, centrally located on the island (Lorvelec 2011) (Fig. 6). That wall is 460 meters long. Since then, most observations of skinks have been along that dry stone wall. The wall is composed of limestone rocks $20-50 \mathrm{~cm}$ in diameter and averages about one meter in width and height, although it is collapsed in many places. Between 2010 and 2015, an ecological study was conducted by the Association AEVA, a student, and the managers of the nature reserve (i.e., the Office National des Forêts (ONF) and the Association Titè). The number of adult skinks in that dry stone wall was estimated to be about 50 individuals total (Schedwill 2014), with the highest abundance in the parts of the wall not collapsed. Some skinks have been observed in other walls on the island, where abundances are significantly lower than in the main wall, and, very rarely, outside the walls. Due to past agricultural activities, the original forest on the island was largely removed centuries ago, except in the westernmost quarter of the island, and the current vegetation is a degraded scrub habitat with occasional trees. The degraded habitat probably has limited both shelter and food for the skinks, thus limiting the habitable area. So, the known maximum extent of occurrence of this species is $1.1 \mathrm{~km}^{2}$, and the primary distribution (area of occupancy) is only $\sim 500 \mathrm{~m}^{2}$, which is probably one of the smallest of any species of vertebrate.

Since September 1998, the Îles de la Petite Terre have had the status of a French national nature reserve. Terre de Bas and Terre de Haut are uninhabited. Tourism is authorized only in the eastern part of Terre de Bas (coconut plantation and surroundings, Fig. 1B) and does not appear to create a disturbance for skinks. In particular, the dry stone wall that hosts the majority of skinks is not frequented by tourists. The most significant threat for this 


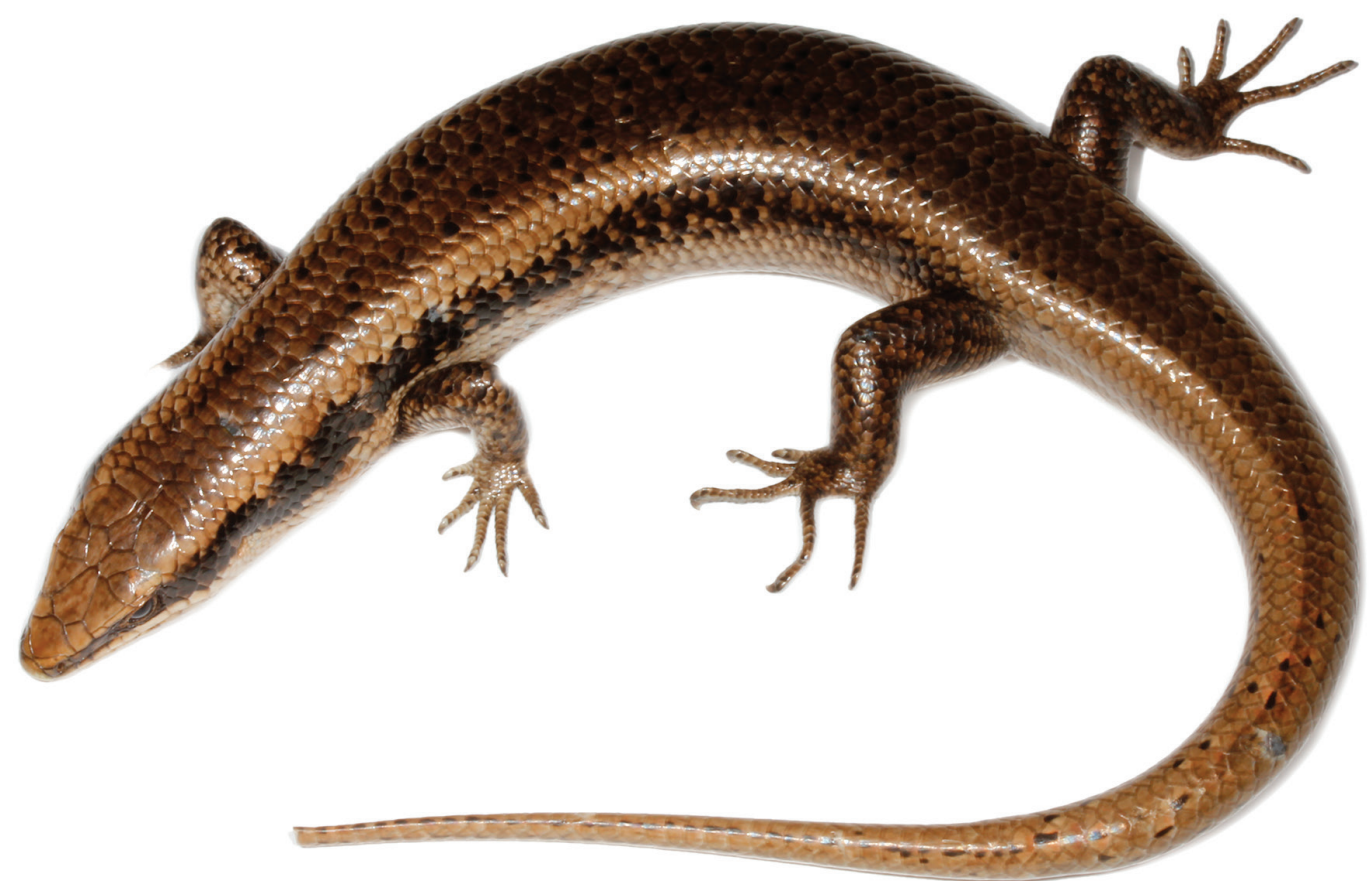

Figure 5. Live adult Mabuya parviterrae sp. nov. (released) from Terre de Bas, Îles de la Petite Terre.

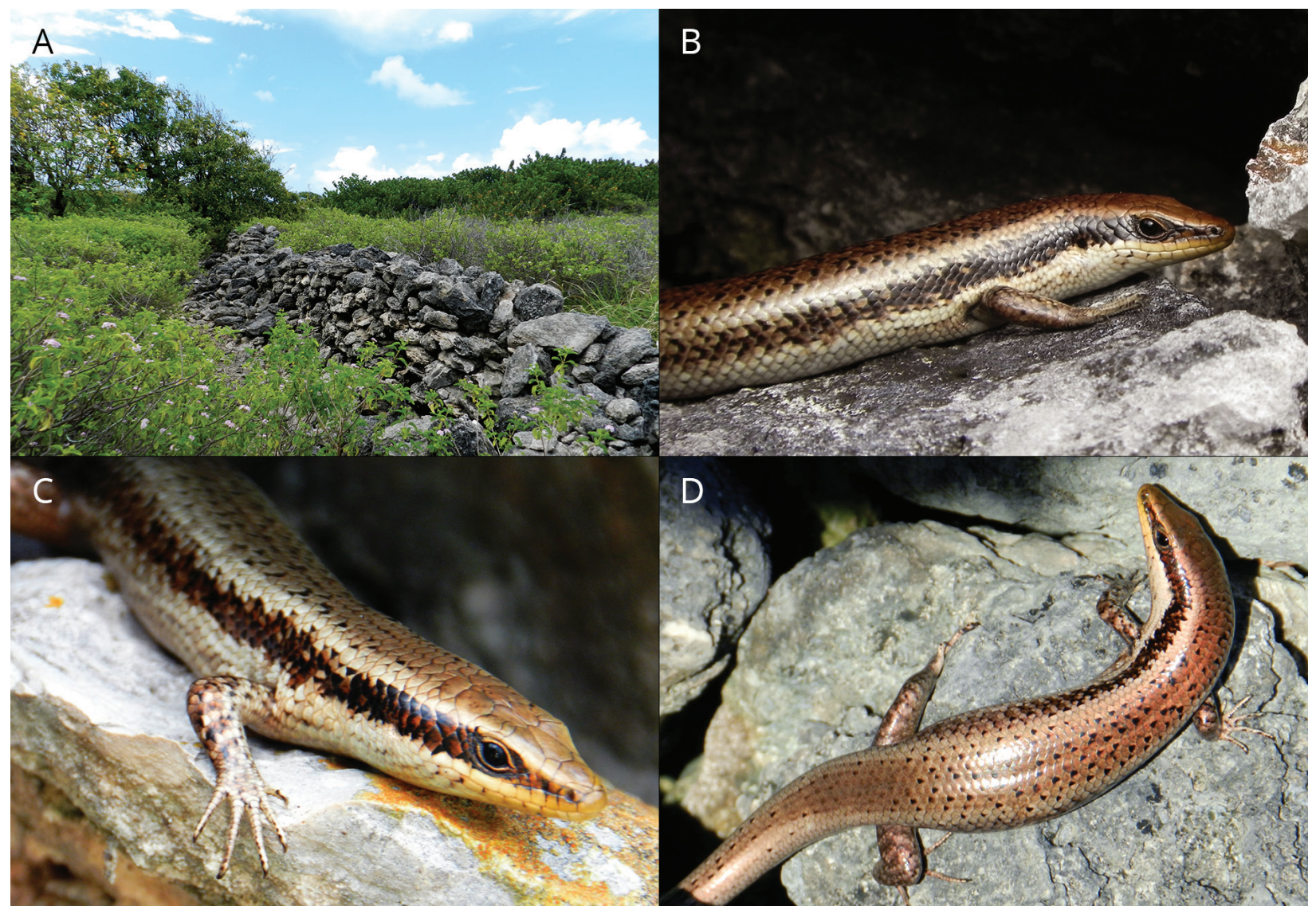

Figure 6. Rock wall habitat (A) and live individuals (B-D) of Mabuya parviterrae sp. nov. on Terre de Bas, Îles de la Petite Terre. 
species is the presence of a large population of black rats (Rattus rattus). These rats are seen in great abundance on and within the stone wall, even during the day, and undoubtedly are predators of the skinks. It is possible that the stone wall provides some (limited) refuge from the rats, because skinks can pass through cracks and other spaces in the stone wall that are too small for a rat. In turn, this may be why the skinks have occupied the stone wall as their primary habitat (Lorvelec et al. 2012).

Based on IUCN Redlist criteria (IUCN 2016), we consider the conservation status of Mabuya parviterrae sp. nov. to be Critically Endangered (CR A2ace). It lives in degraded (deforested in the past, and not recovered) habitat and faces a primary and ongoing threat from an introduced mammalian predator, the Black Rat. In February 2016, Mabuya parviterrae sp. nov. is a species protected by French legislation under the name Mabuya mabouya, and the only known population of that species lives on a nature reserve. Taking advantage of that favorable situation, we think that conservation measures should be taken by Guadeloupean authorities to prevent extinction of the species. Notably, captive breeding programs should be considered, and efforts should be undertaken to remove all introduced mammalian predators from Îles de la Petite Terre (Terre de Bas and Terre de Haut). Collapsed portions of dry stone walls should be restored. Terre de Haut hosts perhaps an undiscovered population. Otherwise, that islet would be a favorable site to create a second population after rat eradication on the two islets. Efforts should be made to restore original habitats (vegetation) to both islands.

Reproduction. The four fully-developed fetuses from the holotype suggest that parturition would have taken place at about the time of collection (i.e., 22 April).

Etymology. The species name (parviterrae) means 'small land' in Latin and is a feminine genitive singular noun, referring to the distribution of the species on Îles de la Petite Terre.

Remarks. Breuil (2002) suggested that Lazell's (1973) brief mention of a skink in Les Saintes was in error, and that he was probably referring to the population of skinks on îles de la Petite Terre. However, the recent report of an endemic skink in Les Saintes (Angin \& Gomès 2015) suggests that Lazell's (1973) original comment was correct. In any case, Lazell did not actually see the lizard, but was referring to observations made by someone else. Now that evidence exists for skinks on both archipelagos, this undocumented and disputed observation is no longer relevant.

\section{Discussion}

The discovery of an endemic skink from Terre de Bas, îles de la Petite Terre, is not surprising given the presence of another endemic lizard species, Anolis chrysops Lazell. A third possible endemic may be the teid Ameiva major Duméril \& Bibron. Breuil $(2002,2009)$ considered it to be from Îles de la Petite Terre based on his interpretations of 19th century documents, including a correspondence of Félix-Louis L'Herminier. However, Ameiva major is usually considered to be an endemic of Martinique (e.g., Baskin \& Williams 1966; Schwartz \& Henderson 1991) and the only known specimens of the species were collected in the 19th century, with the locality "Martinique" (although see Breuil 2002, 2009). If it is actually from Îles de la Petite Terre, it is unclear why the species would have disappeared since the mongoose is not known to have occurred there. In any case, more information is needed to resolve whether Ameiva major is from the Martinique Archipelago or the Guadeloupe Archipelago.

Terre de Bas is $7.5 \mathrm{~km}$ from Guadeloupe (Grande-Terre) and $12 \mathrm{~km}$ from La Désirade. All three islands are on the same bank (Fig. 1A). Today, the seabed between Grande-Terre, Îles de la Petite Terre, and La Désirade is less than $25 \mathrm{~m}$ at its shallowest point, and the water depth between Îles de la Petite Terre and La Désirade is less than 15 $\mathrm{m}$ at its shallowest point. La Désirade also has endemic species and subspecies of reptiles: Anolis desiradei Lazell, Mabuya desiradae Hedges \& Conn, and Sphaerodactylus fantasticus hippomanes Thomas.

Our phylogenetic tree (Fig. 2) includes only 3 of the 9 species of Mabuya because all of the others have disappeared from predation by the introduced mongoose. Future research may be able to increase that number with the use of ancient DNA methods on old museum specimens. For now, the results show that $M$. desiradae and 
M. parviterrae are more closely related than either is to M. dominicana. This is consistent with the definition of the M. guadeloupae species group (Hedges \& Conn 2012), which allies species in the Guadeloupe Archipelago based on morphological data. Until DNA sequence data become available for the remaining species, we refrain from speculating as to the relationships among species in the M. guadeloupae species group.

Determining precisely when species diverged from one another is difficult, whether from molecular clocks or paleogeography. In this case, sequence divergence suggests a Pleistocene separation, which agrees with the divergence of some other species of skinks on Caribbean islands (Hedges \& Conn 2012). During periods of glaciation, sea levels were lower and probably resulted in dry land connections between the main island of Grande Terre and some surrounding islets. Based on the shallow waters separating Grande Terre from Îles de la Petite Terre and La Désirade, a land connection could have occurred as recently as $\sim 12,000$ years ago, during the last glaciation. However, this would assume that subsequent uplift, in addition to sea-level change, did not occur, otherwise there would have not been emergence of land at that time. Also, it would assume that dry land connecting these areas in the past consisted of suitable habitat for skinks. On the other hand, glaciations were a time when habitats in the tropics were drier, reducing the extent of suitable habitats for many species and thus creating refugia. For example, a dry land connection (peninsula) may have existed during the last glaciation, in these areas currently submerged, but it may have been unsuitable for skinks. This can be seen in many areas completely emergent today, where isolated 'islands' of habitat exist separated by areas of unsuitable habitat.

In the case of these skinks, the time estimate from sequence divergence suggests that they diverged earlier in the Pleistocene ( 500,000 years ago). In the future, when DNA sequences become available from the remaining species of Mabuya, and with better paleogeographic data for potential calibrations, it might be possible to estimate divergence times with better precision. Also, considering the genetics of speciation, it might be more appropriate to recognize lineages separated for less than one million years as subspecies instead of species (Hedges et al. 2015). However, until a global decision is made by taxonomists on that issue, which would affect thousands of currently-recognized species of organisms, Mabuya parviterrae sp. nov. is best recognized at the species level.

Concerning the conservation of Mabuya parviterrae, recent studies of fossil sites on nearby islands of Guadeloupe shed some light on the extinction of reptile species and potential threats in the region. On Marie-Galante (Bailon et al. 2015), only two of the eight or nine genera occurring in the Pleistocene are found today on the island. Most or all of those extinctions (or extirpations) occurred since 1492, and include the endemic skink, Capitellum mariagalantae. Because of the close timing of introductions of the mongoose in the West Indies in the late 19th century and subsequent absence or decline of skinks on islands with mongooses, a cause-and-effect relationship is strongly supported (Hedges \& Conn 2012). The mongoose was introduced to Marie-Galante in 1900 (Hedges \& Conn 2012), and that probably explains the extinction of the skink and the other diurnal, ground-dwelling reptile species from that island, including ameivas (Ameiva), curlytails (Leiocephalus), and racers (Alsophis) (Bailon et al. 2015).

On La Désirade, the endemic skink (Mabuya desiradae) has survived but is uncommon. It exists with introduced mammals such as black rats, cats (Felis catus), the raccoon (Procyon lotor), and the mongoose (see discussion below). Predation by cats has been observed on multiple occasions (Métaireau 2014). However, the ameivas, curlytails, and racers known from the pre- and post-Columbian fossil record of La Désirade apparently did not survive past the 19th century (Boudadi-Maligne et al. 2015). Unusually intense habitat alteration by livestock and agriculture on La Désirade has been suggested to have caused the extinctions (Boudadi-Maligne et al. 2015). Certainly, the decline and extinction of species from habitat destruction is widely-known globally, so that is possible. However, these ground-dwelling reptiles are not known to be so sensitive to habitat alteration on other islands, but rather are especially sensitive to predation by the mongoose (Hedges \& Conn 2012). Boudadi-Maligne et al. (2015) excluded the mongoose from consideration because they assumed La Désirade to be mongoose-free.

Recently, mongooses were observed at two separate locations on the northeast end of La Désirade during 
an extensive, island-wide survey of orchids in June and July 2013, confirming its presence on the island (Barré et al. 2014). However, there has been confusion in the past regarding its introduction and presence. Barbour (1930) tentatively considered it to be present, and La Désirade has been included, without qualification, in more recent lists of islands with mongooses (e.g., Nellis \& Everard 1983; Barun et al. 2011) despite publications reporting it to be absent (Pinchon 1967; Lorvelec et al. 2007). This raises several possible scenarios for the history of the mongoose on La Désirade. The simplest is that early reports of its presence were correct and that it was introduced on La Désirade at about the same time as on nearby islands ( 1880-1900), persisting to the present in low numbers. If true, it would agree with the typical history of mongoose introductions, where populations surge to high levels after introduction to an island and then drop to lower levels (Nellis \& Everhard 1983). For example, in Cuba it has been rarely seen since the early 20th century (Barbour 1930; Timm \& Genoways 2003). The same may have been true for La Désirade, which would explain the extinctions and declines of native reptiles and later decline of mongooses. Also, this explanation would not require a second introduction and would agree with early (albeit undocumented) reports of the mongoose on La Désirade. Nonetheless, other possibilities cannot be ruled out. For example, the mongoose may be an old introduction that eventually disappeared from the island, and was then reintroduced more recently. Or La Désirade may have been mongoose-free until very recently when the species was introduced for the first time. Both of these alternative explanations are less likely because they require an extra introduction or conflict with other information as noted above. In any case, an extirpation of the mongoose on La Désirade should be conducted as quickly as possible.

The importance of reptile conservation on La Désirade to that on Terre de Bas, îles de la Petite Terre, is the proximity of the two islands and close relationship of the skinks. The mongoose does not occur on Terre de Bas and there is no evidence that it ever occurred there. Yet, the skinks are in very low numbers and threatened with extinction by degraded habitat and the presence of another invasive species, the Black Rat. The more we can learn about the dynamics of invasive species and how the many different types of threats interact to cause species declines, the better we can manage and protect species from extinction.

\section{Acknowledgements}

The field work was conducted under the scope of a project to study the conservation of skinks of the French West Indies, hosted by the Association pour l'Étude et la protection des Vertébrés et végétaux des petites Antilles - AEVA (OL, NB, CP), since 2012. We thank the Direction de l'Environnement, de l'Aménagement et du Logement (DEAL) de la Guadeloupe, especially Luc Legendre, for funding, authorizations to collect biological material of a protected species, and authorization to transport that material to the USA. We thank managers of the Réserve Naturelle Nationale des îles de la Petite Terre: the Office National des Forêts (ONF), especially the Conservator René Dumont, for authorizations for working and sampling in the reserve, and the Association Titè, i.e., its President Raoul Lebrave and all the rangers for their participation in field work. We also thank Béatrice lbéné (Association pour la Sauvegarde et la réhabilitation de la Faune des Antilles - ASFA) for examining the holotype with radiography, and volunteers of Association AEVA for assistance in the field. NV was supported by a grant from the Muséum National d'Histoire Naturelle (MNHN). We thank Damien Fourcy (INRA, UMR Écologie et Santé des Écosystèmes) for the mapping of îles de la Petite Terre. We thank the staff of the Center for Biodiversity, in particular Sarah Hanson for assembling maps, Angela Lu for assembling figures, Allison Loveless for generating DNA sequences, and Angela Marion for conducting molecular phylogenetic analyses. Daniel Berman (Temple University) provided guidance in Latin orthography. SBH was supported by the Center for Biodiversity, Temple University, and by grants from the U.S. National Science Foundation. We thank two anonymous reviewers for critically reading the manuscript.

\section{Literature Cited}

Angin B, Gomès R (2014) First report of a skink population on Les Saintes (Guadeloupe, FWI). Caribbean Herpetol- 
ogy $52,1-2$.

Bailon S, Bochaton C, Lenoble A (2015) New data on Pleistocene and Holocene herpetofauna of Marie Galante (Blanchard Cave, Guadeloupe Islands, French West Indies): Insular faunal turnover and human impact. Quaternary Science Reviews, 128, 127-137.

Barré N, Chauchoy A, Citadelle G, Citadelle M (2014) Inventaire des orchidées et cactus de la Désirade, approche écologique. I'Association Guadeloupéenne d'Orchidophilie AGO, 19p +13 maps.

Barun A, Hanson CC, Campbell KJ, \& Simberloff D (2011) A review of Small Indian Mongoose management and eradications on islands. Pages 17-25 in Veitch CR, Clout MN \& Towns DR (eds.). 2011. Island invasives: eradication and management. IUCN, Gland, Switzerland.

Baskin JN, Williams EE (1966) The Lesser Antillean Ameiva (Sauria, Teiidae). Re-evaluation, zoogeography, and the effects of predation. Studies on the Fauna of Curaçao and other Caribbean Islands, 23, 144-176.

Boudadi-Maligne M, Bailon S, Bochaton C, Casagrande F, Grouad S, Serrand N, Lenoble A (2015) Evidence for historical human-induced extinctions of vertebrate species on La Désirade (French West Indies). Quaternary Research, doi:10.1016/j.yqres.2015.11.001.

Breuil M (2002) Histoire naturelle des amphibiens et reptiles terrestres de l'Archipel Guadeloupéen. Guadeloupe, Saint-Martin, Saint-Barthélemy. Paris, MNHN, Institut d'Écologie et de Gestion de la Biodiversité, Service du Patrimoine Naturel, Patrimoines naturels, 54, 1-348.

Breuil M (2009) The terrestrial herpetofauna of Martinique: past, present, future. Applied Herpetology, 6, $123-149$.

Corke D (1992) The status and conservation needs of the terrestrial herpetofauna of the Windward Islands (West Indies). Biological Conservation, 62, 47-58.

Gomès R, Ibéné B (2013) Mabuya desiradae (Désirade Skink). Distribution. Caribbean Herpetology, $43,1$.

Hedges SB (2014) The high-level classification of skinks (Reptilia, Squamata, Scincomorpha). Zootaxa, 3765, 317-338.

Hedges SB, Marin J, Suleski M, Paymer M, Kumar S (2015) Tree of life reveals clock-like speciation and diversification. Molecular Biology and Evolution, 32, 835-845.

IUCN (2016) IUCN redlist of threatened species. Cambridge, United Kingdom: International Union for the Conservation of Nature. Available from http://www.iucnredlist.org/ (accessed 1 January 2016).

Lazell JD (1973) The lizard genus Iguana in the Lesser Antilles. Bulletin of the Museum of Comparative Zoology, 145, 1-28.

Lewis DS, Veen RV, Wilson BS (2011) Conservation implications of small Indian mongoose (Herpestes auropunctatus) predation in a hotspot within a hotspot: the Hellshire Hills, Jamaica. Biological Invasions, 13, 25-33.

Lorvelec O (2011) Mabuya mabouya (Greater Martinique Skink). Conservation. Caribbean Herpetology, $19,1$.

Lorvelec O, Barré N, Pavis C (2012) Les dernières populations de Scinques dans les Antilles françaises: état des connaissances et propositions d'actions. Association pour l'Etude et la protection de Vertébrés et végétaux des petites Antilles, Petit-Bourg, Guadeloupe, $35 \mathrm{pp}$.

Lorvelec O, Levesque A, Leblond G, Jaffard M-E, Barré N, Feldmann P, Pascal M, Pavis C (2000) Suivi Ecologique des Reptiles, Oiseaux et Mammifères aux Îles de la Petite Terre (Commune de La Désirade, Guadeloupe). Années 1998 et 1999 . Association pour l'Etude et la protection de Vertébrés et végétaux des petites Antilles, Petit-Bourg, Guadeloupe, 104 pp.

Lorvelec O, Pascal M, Pavis C, Feldmann P (2007) Amphibians and reptiles of the French West Indies: Inventory, threats and conservation, Applied Herpetology, 4, 131-161.

Métaireau P (2014) Inventaire et cartographie de la population de scinques Mabuya desiradae (Mabuyidae) des espaces naturels de la Désirade. Report. Professional Degree EDEN. Univ. Montpellier 2. Association Tité. ONF. Association AEVA, Guadeloupe, 30 pp.

Nellis DW, Everard COR (1983) The biology of the mongoose in the Caribbean. Studies on the Fauna of Curaçao and other Caribbean Islands 1, 1-162. 
Paré T, Lorvelec O (2012) Mabuya desiradae (Désirade Skink). Conservation. Caribbean Herpetology, 38, 1.

Pinchon R (1967) Quelques aspects de la nature aux Antilles. Ozanne, Fort-de-France.

Ronquist F, Teslenko M, van der Mark P, Ayres DL, Darling A, Höhna S, Larget B, Liu L, Suchard MA, Huelsenbeck JP (2012) MrBayes 3.2: efficient Bayesian phylogenetic inference and model choice across a large model space. Systematic Biology, 61, 539-542.

Schedwill P (2014) Étude de la population de Mabuya cf. desiradae (Squamata: Mabuyidae) de Terre de Bas (îles de la Petite Terre, commune de La Désirade, Guadeloupe). Report. ERASMUS Programme. Univ. Antilles-Guyane, Association Tité, ONF, Association AEVA, Guadeloupe, 61 pp.

Schwartz A, Henderson RW (1991) Amphibians and reptiles of the West Indies: descriptions, distributions, and natural history. University of Florida Press, Gainesville, Florida, $720 \mathrm{pp}$.

Tamura K, Stecher G, Peterson D, Filipski A, Kumar S (2013) MEGA6: Molecular Evolutionary Genetics Analysis version 6.0. Molecular Biology and Evolution, 30, 2725-2729.

Timm RM, Genoways HM (2003) West Indian mammals from the Albert Schwartz collection: biological and historical information. Scientific Papers, Natural History Museum, University of Kansas, 29, 1-47. 